\section{General Anesthesia to Low Flows with Sevofluran in Patients of Colecistectomy by Video Laparoscopy, Regional National Hospital "San Juan De Dios”, San Miguel, year 2019}

\author{
José Mauricio-Aparicio ${ }^{1,2 *}$, Mario Luis-Quito ${ }^{3}$, Eneyda \\ María-Amaya $^{3}$, Irving Balmore-Chávez ${ }^{3}$ and Joseline \\ Milagro-Castillo ${ }^{3}$
}

${ }^{1}$ Internist Physician and Anesthesiologist, Universidad de El Salvador - FMO, El Salvador

${ }^{2}$ Head of the Department of Anesthesiology of The National Regional Hospital San Juan de Dios of San Miguel, El Salvador

${ }^{3}$ Graduate in Anesthesiology and Inhalotherapy, Universidad de El Salvador - FMO, El Salvador

\begin{abstract}
Objective: To assess the effectiveness of general anesthesia at low flows with Sevoflurane in patients with Video laparoscopy Cholecystectomy.

Methodology: Parallel clinical trial, 80 patients who met the inclusion criteria were studied, divided into two treatment groups; treatment 1 general anesthesia at low flows with oxygen at $1 \mathrm{lts} / \mathrm{min}$ and sevoflurane, and treatment 0 general anesthesia at high flow with oxygen at $3 \mathrm{Its} / \mathrm{min}$ and sevoflurane. The degree of humidification and temperature of the inspired gases, the time of recovery of anesthesia, oxygen consumption and sevoflurane per minute of use, and the presence of aesthetic gases in the operating room environment
\end{abstract}

*Corresponding author: José Mauricio-Aparicio, Head of the Department of Anesthesiology of The National Regional Hospital San Juan de Dios of San Miguel, El Salvador, Tel: +503 71708903; E-mail: jmvoc19@yahoo.com

Citation: Mauricio-Aparicio J, Luis-Quitoc M, María-Amayad E, Balmore-Chávezd I, Milagro-Castilloc J (2020) General Anesthesia to Low Flows with Sevofluran in Patients of Colecistectomy by Video Laparoscopy, Regional National Hospital San Juan De Dios, San Miguel, year 2019. J Anesth Clin Care 7: 049.

Received: February 18, 2020; Accepted: March 04, 2020; Published: March 11,2020

Copyright: (c) 2020 Mauricio-Aparicio J, et al. This is an open-access article distributed under the terms of the Creative Commons Attribution License, which permits unrestricted use, distribution, and reproduction in any medium, provided the original author and source are credited. were evaluated. The results were processed through the statistical program SPSS version 25.0, under statistical tests of T Student and U Mann-Whitney. A bilateral statistical significance at a value of $p \leq$ 0.05 was considered.

Result: The relative humidity and temperature of the inspired gases was higher in the treatment at low flows, from minute 15 with $p$ $=0.000$. Oxygen consumption and sevoflurane reflecting, is lower for low flows with $p=0.000$. The recovery time of the anesthesia increased by an average of $10 \mathrm{~min}$ compared to the high flow group. The presence of anesthetic gases inside the operating room could not be verified by this study.

Conclusion: General anesthesia at low flows with Sevoflurane is effective as the patient receives higher relative humidity and temperature of the inspired gases, in addition to reducing oxygen consumption and sevoflurane.

Keywords: Effectiveness; General anesthesia; Low flows; Sevoflurane; Video laparoscopy cholecystectomy

\section{Introduction}

Aldrete defines the low flows as the administration of gaseous miscellanies, from the immediately low limit of the alveolar ventilation per minute, up to the flow needed only to fulfill the basic consumption of oxygen and the absorption of the anesthetic agent [1].

For the definition of low flows, we owe to help of classifications previously described by Baker, the Simionescu classification and captured later by Baxter in its review of low and minimal flows, which can be observed next: [2]

\begin{tabular}{|c|c|}
\hline Metabolic flow & $250 \mathrm{~mL} / \mathrm{min}$ \\
\hline Minimum flow & 250 to $500 \mathrm{~mL} / \mathrm{min}$ \\
\hline Low flows & 500 to $1,000 \mathrm{~mL} / \mathrm{min}$ \\
\hline Medium flows & 1 to $2 \mathrm{~L} / \mathrm{min}$ \\
\hline High flows & 2 to $4 \mathrm{~L} / \mathrm{min}$ \\
\hline Very high flows & $>4 \mathrm{~L} / \mathrm{min}$ \\
\hline
\end{tabular}

If a smaller flow of fresh gas is established, the anesthetic gases in the patient's exhaled air are returned through closed or semi-closed re-breathing systems, all of which establishes a series of benefits that can be divided into clinical, economic and ecological [3].

We are immersed in a process of globalization where the role of the anesthetist must be that of a great planner, using strategies in decision-making to reduce costs and maximize the benefits of anesthetic procedures, it is for this reason that anesthesia at low movements have taken a strong resurgence in recent years, due to clinical, economic, ecological factors and modernization in monitoring technology. Thus, with the arrival of different modern anesthesia machines in the environment, the availability of complete monitoring of anesthetic gases and vapors, the constant use of advantageous but expensive 
inhaling agents such as sevoflurane and due to the limitation in the use of Health resources, especially in developing countries such as El Salvador, is that this study aims to obtain evidence-based information on the difficulty of general anesthesia at low levels with Sevoflurane in Video laparoscopic Cholecystectomy patients at the Regional National Hospital "San Juan de Dios", San Miguel.

\section{Materials and Methods}

A study was carried out, which by design is a controlled, randomized clinical trial, with parallel groups, the sampling technique was of simple random type, 80 patients were included: men and women, ASA I and II, undergoing celectoscopic cholecystectomy, under balanced general anesthesia, between 18 and 60 years old and BMI between 18.5 and $30 \mathrm{~kg} / \mathrm{m} 2$, with surgical time $<2 \mathrm{hrs}$ and who signed the informed consent (Figure 1).

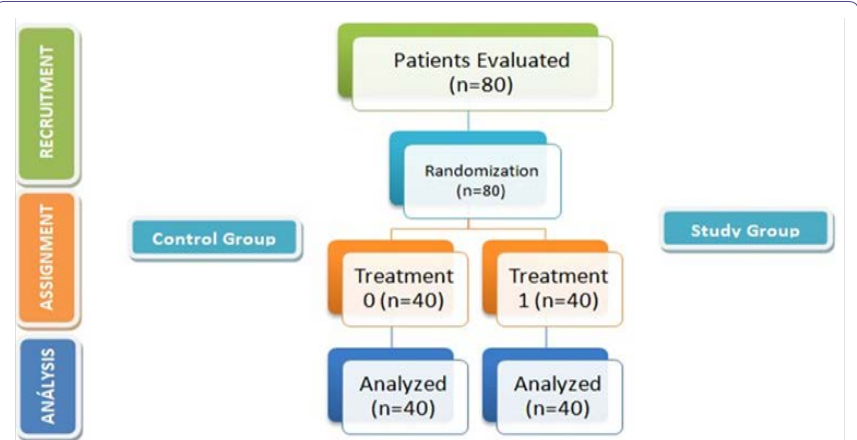

Figure 1: Flowchart of randomized clinical trial.

Two groups were defined: treatment 1: general anesthesia at low oxygen flow $(1 \mathrm{~L} / \mathrm{min})$ with sevoflurane. Pre-oxygenation with nasal cannulae is performed at $5 \mathrm{Lts} / \mathrm{min}^{\mathrm{FiO}}{ }_{2} .40 \%$ for 3 minutes, at the same time, a pre-filling of the circular circuit with the overpressure technique with a flow of $\mathrm{O}_{2} 5 \mathrm{~L} / \mathrm{min}$ and sevoflurane $8 \mathrm{Vol} \%$ for 3 $\mathrm{min}$. After that time Atropine $0.5 \mathrm{mg}$ IV is administered as standard dose and propofol $50 \mathrm{mg}$ IV plus positive pressure ventilation with face mask with a flow of $\mathrm{O}_{2} 5 \mathrm{~L} / \mathrm{min}$ and sevoflurane $8 \mathrm{vol} \%$, when the patient loses consciousness, fentanyl is administered at a dose of 2 $\mu \mathrm{g} / \mathrm{kg}$, propofol $2.5 \mathrm{mg} / \mathrm{kg}$, succinylcholine $2 \mathrm{mg} / \mathrm{kg} \mathrm{IV}$, laryngoscopy and orotracheal intubation. The patient is connected to mechanical ventilation and administered of cisatracurium at dose $0.1 \mathrm{mg} / \mathrm{kg} \mathrm{IV}$.

When the patient reaches the target MAC value $1.0-1.25$, the flow with $100 \%$ oxygen is reduced to $1.0 \mathrm{~L} / \mathrm{min}$ and the vaporizer dial is changed between values of 3 to $5 \mathrm{Vol} \%$.

Prior to the end of the procedure, a reduction to the vaporizer agent is performed to $0 \%$ approximately 10 minutes before the end of surgery, where oxygen flow is maintained at 1 liter per minute until the patient begins to have a pattern respiratory. The patient is transitioned to spontaneous breathing with $100 \%$ oxygen at 6 liters per minute and will be maintained until the patient meets the extubation criteria.

Treatment 0: general anesthesia at high oxygen flows $(3 \mathrm{~L} / \mathrm{min})$ with sevoflurane. Pre-oxygenation and induction similar to treatment group 1 and after connecting the patient to mechanical ventilation and administration of cisatracurium is adjusted the flow of fresh gas with $100 \%$ oxygen to $3 \mathrm{~L} / \mathrm{min}$ and the dial of the sevoflurane vaporizer is placed between $2-2.5 \mathrm{Vol} \%$, keeping a MAC between $1.0-1.25$.
Prior to the end of the procedure, a reduction to the vaporizer agent is performed to $0 \%$ approximately 10 minutes before the end of surgery, where oxygen flow is maintained at 1 liter per minute until the patient begins to have a pattern respiratory. The patient is transitioned to spontaneous breathing with $100 \%$ oxygen at 6 liters per minute and will be maintained until the patient meets the extubation criteria.

For both groups, at the end of the anesthetic procedure a $50 \mathrm{cc}$ sample of ambient air from the operating room was taken and passed through the gas analyzer of the Mindray A5 anesthesia machine.

It was recorded by the observation guide, the relative humidity in $\%$, and the temperature of the gases inspired by every 5 minutes, the amount of $\mathrm{O}_{2}$ used and the vol\% on the sevoflurane dial every 3 minutes, at the close of the sevoflurane vaporizer dial, the recovery of anesthesia was recorded by the modified Aldrete scale every 5 minutes and a note 8 was instituted as a recovery value, environmental pollution expressed in MAC value at the end of the anesthetic procedure, and sevoflurane consumption is defined by the use of the following formulations:

\section{Formulation 1}

Anesthetic vapor volume $=(\%)$ anesthetic X (fresh gas flow / $100-$ (\%) anesthetic)

\section{Formulation 2}

Liquid volume $=$ Volume of steam used $/$ Vapor produced per $\mathrm{ml}$ of anesthetic.

In each $\mathrm{ml}$ of liquid sevoflurane there are $182.7 \mathrm{ml}$ of anesthetic vapor [4].

The statistical analysis was carried out using the SPSS v 25.0 program, after obtaining the data, the Shapiro-Wilk normal test was performed, the data group to which a normal distribution was determined was performed the statistical test of t-student, and when the $\mathrm{U}$ Mann-Whitney test was obtained, and a bilateral significance with a value of $\mathrm{p} \leq 0.05$ was considered.

\section{Results}

A total of 80 patients were studied: $n=40(50 \%)$ treatment group $0, \mathrm{n}=40(50 \%)$ treatment group 1, with an average age of $38.68 \pm$ 12.08 for treatment 0 and $35.80 \pm 12.36$ for treatment 1 , I predominance the female sex for both treatment groups $55 \%$ and $60 \%$, and a physical stage ASA I $70 \%$ and $62.5 \%$ respectively (Table 1 ).

\begin{tabular}{|c|c|c|}
\hline Groups & $\begin{array}{c}\text { Treatment } 1 \\
\mathbf{N}=\mathbf{4 0}\end{array}$ & $\begin{array}{c}\text { Treatment } 0 \\
\mathbf{N}=\mathbf{4 0}\end{array}$ \\
\hline Age & $\begin{array}{c}38.68 \pm 12.08 \\
22 / 59\end{array}$ & $\begin{array}{c}35.80 \pm 12.36 \\
22 / 59\end{array}$ \\
\hline Weight & $\begin{array}{c}72.56 \pm 9.87 \\
50.0 / 91.6\end{array}$ & $\begin{array}{c}69.76 \pm 9.52 \\
50.0 / 92.0\end{array}$ \\
\hline Size & $\begin{array}{c}164.50 \pm 8.92 \\
148.0 / 180.0\end{array}$ & $\begin{array}{c}169.02 \pm 9.34 \\
148.0 / 182.0\end{array}$ \\
\hline BMI & $\begin{array}{l}26.65 \pm 2.09 \\
22.22 / 29.79\end{array}$ & $\begin{array}{l}25.99 \pm 2.31 \\
22.00 / 29.72\end{array}$ \\
\hline $\operatorname{Sex}(M / F)$ & $\begin{array}{l}45.0 \%(18) / \\
55.0 \%(22)\end{array}$ & $\begin{array}{l}40.0 \%(16) / \\
60.0 \%(24)\end{array}$ \\
\hline ASA (I Y II) & $\begin{array}{l}70.0 \%(28) / \\
30.0 \%(12)\end{array}$ & $\begin{array}{l}62.5 \%(25) / \\
37.5 \%(15)\end{array}$ \\
\hline
\end{tabular}

Table 1: General Data. 
The moisture and the temperature of the inspired gases increases from $15 \mathrm{~min}$ in the anesthesia low flows, with a bilateral significance of $p=0.000$, obtaining the registered maximum average of relative moisture for the treatment 1 of $98.20 \pm 1.476 \%$ to $105 \mathrm{~min}$ and of $61.59 \pm 11.554 \%$ to $90 \mathrm{~min}$ for the treatment 0 , as for the temperature, the biggest registered one was $25.960 \pm 1.1436{ }^{\circ} \mathrm{C}$ to $75 \mathrm{~min}$ for the treatment 1 and $24.172 \pm 0.7911{ }^{\circ} \mathrm{C}$ to $60 \mathrm{~min}$, for the treatment 0 , with a bilateral significance of $\mathrm{p}=0.000$ (Figures 2 and 3 ).

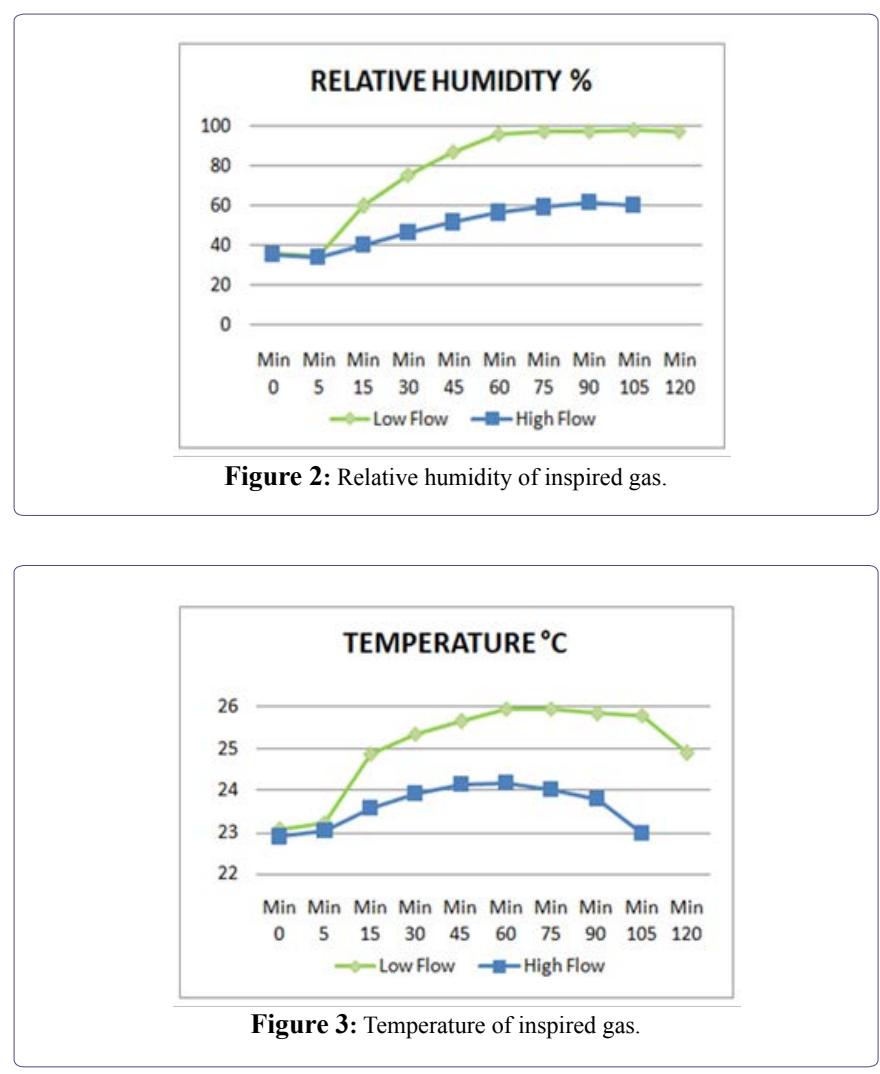

The time of use of sevoflurane had an average of $69.30 \pm 17.393$ min for the group 1 and $72.72 \pm 17.653$ min for the group 0 , with a bilateral significance of $p=0.382$, and the time of use of oxygen was $90.77 \pm 17.483 \mathrm{~min}$ for the treatment 1 and for the treatment $0,87.45$ \pm 17.445 min with a bilateral significance of $p=0.452$.

The sevoflurane consumption had an average for the treatment 1 , $16.55 \pm 2.084 \mathrm{ml}$ and for the treatment $0,33.02 \pm 6.415 \mathrm{ml}$, with a bilateral significance of $\mathrm{p}=0.000$, and the time of consumption of oxygen was to $148.85 \pm 18.520 \mathrm{~L}$, for the treatment 1 and $295.12 \pm$ $59.927 \mathrm{~L}$ for the treatment 0 , with a bilateral significance of $\mathrm{p}=0.000$ (Figures 4 and 5).

The time of recovery of the anesthesia in which a note bigger than 8 was obtained in the modified Aldrete scale was to $20 \mathrm{~min}$ in the group of treatment 1 , with an average of $9.89 \pm 1.811$ and for the group 0 to $10 \mathrm{~min}$ with an average of $8.85 \pm 1.833$ (Figure 6).

As for the recording of environmental pollution, no data were obtained.

\section{Discussion}

The patients with mechanical ventilation lose the functions of the top airway, of warming and humidification of the inspired gases [5]. On having been ventilated by dry and cold gases, they present a continuous loss of moisture and heat that it predisposes to complications of the airway, such as: alterations of the mucociliary transport, thickening of secretions, dyskinesia ciliary and desquamation epithelial, which drives to hypothermia, hypoxemia and atelectasias to avoid these complications, the patients submitted to anesthetic procedures with intubation endotracheal it is necessary to provide gases with a relative moisture of between $95-100 \%$ and a temperature between the status from 28 to $34{ }^{\circ} \mathrm{C}[6,7]$.
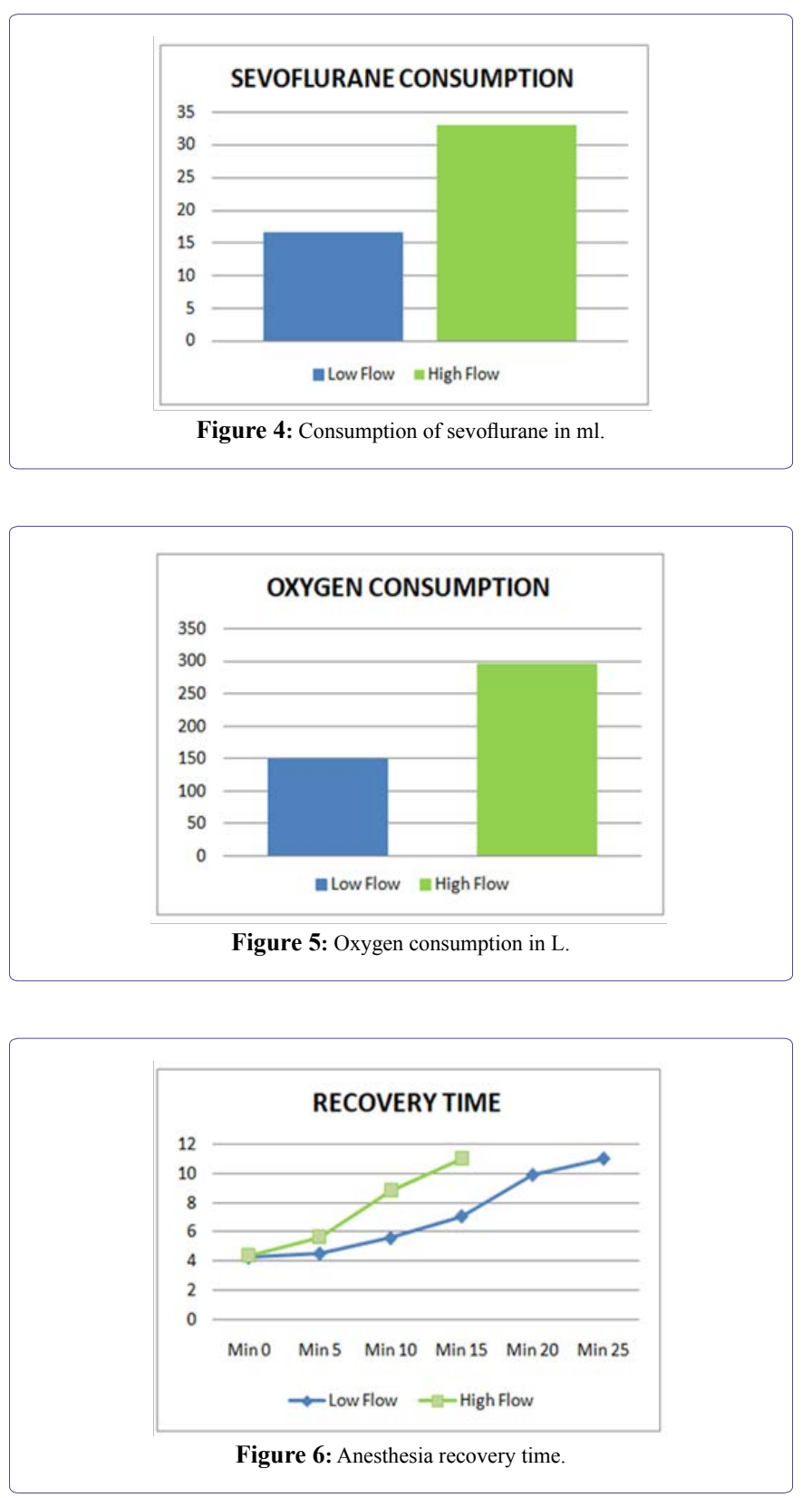

José $\mathrm{S}$, et al., in 2017 perform a meta-analysis on the effects of different flows of fresh gas with or without a heat and humidity exchanger on the humidity of inhaled gas in adults under general anesthesia, the results have concluded that a higher humidity of the inspired gases 
is obtained using low flows, in comparison with the high flows with IC 95\%: 4, 53 a 9, 86; $p<0,001$ [8].

The results of our study imply that general anesthesia and low flows contribute to increase the humidity and temperature of inspired gases, as described in the literature, reducing the implicit complications of an artificial airway.

Ho-Geol Ryu, et al., implemented a low flow policy in 2011 (1 L/ min) by increasing the number of anesthetic hours per sevoflurane bottle from $250 \mathrm{ml}$ to 10.5 hours per bottle to 17.4 hours, with an increase of $73.7 \%$. Gaston M, et al., in 2008 found that the amount of liquid halothane used went from $20 \mathrm{ml}$ per hour, to $7.68 \mathrm{ml} \pm 0.58$ for the first hour, and from $5.25 \mathrm{ml}$ for the second hour of surgery in procedures that lasted more than one hour, with the use of low flows (1 L/min) $[9,10]$.

As for the recovery time of anesthesia, this is higher in anesthesia at low flows, despite that the consumption of oxygen and sevoflurane is not increased due to these factors, Checking as described by Christian Hönemann BM Low flow anesthesia, minimum flow and metabolic flow "clinical techniques for use with reinhalation system", in 2004 [11].

Our investigation showed that oxygen consumption is reduced by $50 \%$ and in the case of sevoflurane in anesthesia at low flows, 18.11 hours of anesthesia per $250 \mathrm{ml}$ bottle occurs, contrary to the control group, where 9.26 hours per bottle occurs.

In the case of environmental pollution, the research group did not have the specific equipment to measure the presence of anesthetic gases in the operating room, so it was not possible to record data and check this variable, despite this, there is a lot of theory which supports that the use of anesthesia at low flows reduces the presence of anesthetic agents, such as that performed by Leonardo A., in 2001 where he demonstrated a reduction in the amount of isoflurane removed to the operating room, of 1.26 MAC ( with $4 \mathrm{~L} / \mathrm{min}$ ), at $0.72 \mathrm{MAC}$ (with $1 \mathrm{~L} / \mathrm{min}$ ) and at $0.46 \mathrm{MAC}$ (with $0.5 \mathrm{~L} / \mathrm{min}$ ). When the flow was reduced from 4 to 1 and from 4 to $0.5 \mathrm{~L} / \mathrm{min}$, the elimination fell to $56.7 \%$ and $36.2 \%$, with a decrease in pollution of $43.3 \%$ and $63.8 \%$ respectively [12].

\section{Conclusion}

At the end of the research topic, we declared as a study group that we have no conflicts of interest, economic, institutional, work or personal.

It is concluded that general anesthesia at low flows with sevoflurane is effective in patients with video laparoscopic cholecystectomy, San Miguel de Dios Regional National Hospital in San Miguel, since it provides a higher relative humidity and temperature of the inspired gases, than in the general anesthesia at low flows with sevoflurane, the time to wake up post-anesthetic is longer, a lower consumption of oxygen and sevoflurane was demonstrated by anesthetic procedure when using anesthesia at low flows, achieving economic savings, and With respect to anesthetic risk, it is demonstrated that it is a safe technique, similar in safety to general anesthesia at high flows; not having trans or post- anesthetic morbi-mortality, in both treatment groups.

\section{References}

1. Aldrete JA (2004) THEORETICAL-PRACTICAL ANESTHESIOLOGY TEXT. Editorial El Manual Moderno, Mexico, 970-729-059-5.

2. Portela-Ortiz JM, Hernández-Cortés C, Delgadillo-Arauz DC (2015) Low Flows in Anesthesia. Mexican Journal of Anesthesiology 38: 352-355.

3. Baum JA (1995) Low-flow anaesthesia. Anaesthesia. 50: 37-44.

4. Laster MJ, Fang Z, Eger EI (1994) Specific gravities of desflurane, enflurane, halothamo, isoflurane, amd sevoflurane. Anesth Analg 78: 11521153.

5. Sylvester J, Konstantatos A (2017) Humidity in Anesthesia. Anaesthesia Tutorial of the Week Page no: 1-4.

6. Hernández-Jiménez C,Olmos-Zuñiga JR, García-Torrentera R, Jasso R, Solís-Bravo T, et al. (2011) Effects of gas humidification tion on mechanical ventilation: An experimental study. Revista del Instituto Nacional de Enfermedades Respiratorias 70: 247-251.

7. Parisoto A (2003) Patient care with mechanical respiratory assistance. IntraMed.

8. Braz JRC, Braz MG, Hayashi Y, Martins RHG, Betini M, et al. (2017) Effects of different fresh gas flows with or without a heat and moisture exchanger on inhaled gas humidity in adults undergoing general anaesthesia: A systematic review and meta-analysis of randomized controlled trials. Eur J Anaesthesiol 34: 515-525.

9. Ryu HG, Lee JH, Lee KK, Gil NS, Kim CS, et al. (2011) The effect of low fresh gas flow rate on sevoflurane consumption. Korean J Anesthesiol 60: 75-77.

10. Gastón M, et al. (2009) Balanced General Anesthesia with Low Flows. Cochabamba: Bolivian Medical Gazette, 32: 1012-2966.

11. Hönemann C, Mierke B (2004) Low Flow, Minimum Flow and Metabolic Flow Anesthesia: Clinical techniques for use with reinhalation systems. Dräger, Lübeck, Germany.

12. Cost of general anesthesia with high, medium, low and minimal flows. Comparative Study. Guillermo Almenara Irigoyen National Hospital. L., Candle. Peru. Lima: s.n. 


\section{If}

Advances In Industrial Biotechnology | ISSN: 2639-5665

Advances In Microbiology Research | ISSN: 2689-694X

Archives Of Surgery And Surgical Education | ISSN: 2689-3126

Archives Of Urology

Archives Of Zoological Studies | ISSN: 2640-7779

Current Trends Medical And Biological Engineering

International Journal Of Case Reports And Therapeutic Studies | ISSN: 2689-310X

Journal Of Addiction \& Addictive Disorders | ISSN: 2578-7276

Journal Of Agronomy \& Agricultural Science | ISSN: 2689-8292

Journal Of AIDS Clinical Research \& STDs | ISSN: 2572-7370

Journal Of Alcoholism Drug Abuse \& Substance Dependence | ISSN: 2572-9594

Journal Of Allergy Disorders \& Therapy | ISSN: 2470-749X

Journal Of Alternative Complementary \& Integrative Medicine | ISSN: 2470-7562

Journal Of Alzheimers \& Neurodegenerative Diseases | ISSN: 2572-9608

Journal Of Anesthesia \& Clinical Care | ISSN: 2378-8879

Journal Of Angiology \& Vascular Surgery | ISSN: 2572-7397

Journal Of Animal Research \& Veterinary Science | ISSN: 2639-3751

Journal Of Aquaculture \& Fisheries | ISSN: 2576-5523

Journal Of Atmospheric \& Earth Sciences | ISSN: 2689-8780

Journal Of Biotech Research \& Biochemistry

Journal Of Brain \& Neuroscience Research

Journal Of Cancer Biology \& Treatment | ISSN: 2470-7546

Journal Of Cardiology Study \& Research | ISSN: 2640-768X

Journal Of Cell Biology \& Cell Metabolism | ISSN: 2381-1943

Journal Of Clinical Dermatology \& Therapy | ISSN: 2378-8771

Journal Of Clinical Immunology \& Immunotherapy | ISSN: 2378-8844

Journal Of Clinical Studies \& Medical Case Reports | ISSN: 2378-8801

Journal Of Community Medicine \& Public Health Care | ISSN: 2381-1978

Journal Of Cytology \& Tissue Biology | ISSN: 2378-9107

Journal Of Dairy Research \& Technology | ISSN: 2688-9315

Journal Of Dentistry Oral Health \& Cosmesis | ISSN: 2473-6783

Journal Of Diabetes \& Metabolic Disorders | ISSN: 2381-201X

Journal Of Emergency Medicine Trauma \& Surgical Care | ISSN: 2378-8798

Journal Of Environmental Science Current Research | ISSN: 2643-5020

Journal Of Food Science \& Nutrition | ISSN: 2470-1076

Journal Of Forensic Legal \& Investigative Sciences | ISSN: 2473-733X

Journal Of Gastroenterology \& Hepatology Research | ISSN: 2574-2566
Journal Of Genetics \& Genomic Sciences | ISSN: 2574-2485

Journal Of Gerontology \& Geriatric Medicine | ISSN: 2381-8662

Journal Of Hematology Blood Transfusion \& Disorders | ISSN: 2572-2999

Journal Of Hospice \& Palliative Medical Care

Journal Of Human Endocrinology | ISSN: 2572-9640

Journal Of Infectious \& Non Infectious Diseases | ISSN: 2381-8654

Journal Of Internal Medicine \& Primary Healthcare | ISSN: 2574-2493

Journal Of Light \& Laser Current Trends

Journal Of Medicine Study \& Research | ISSN: 2639-5657

Journal Of Modern Chemical Sciences

Journal Of Nanotechnology Nanomedicine \& Nanobiotechnology | ISSN: 2381-2044

Journal Of Neonatology \& Clinical Pediatrics | ISSN: 2378-878X

Journal Of Nephrology \& Renal Therapy | ISSN: 2473-7313

Journal Of Non Invasive Vascular Investigation | ISSN: 2572-7400

Journal Of Nuclear Medicine Radiology \& Radiation Therapy | ISSN: 2572-7419

Journal Of Obesity \& Weight Loss | ISSN: 2473-7372

Journal Of Ophthalmology \& Clinical Research | ISSN: 2378-8887

Journal Of Orthopedic Research \& Physiotherapy | ISSN: 2381-2052

Journal Of Otolaryngology Head \& Neck Surgery | ISSN: 2573-010X

Journal Of Pathology Clinical \& Medical Research

Journal Of Pharmacology Pharmaceutics \& Pharmacovigilance | ISSN: 2639-5649 Journal Of Physical Medicine Rehabilitation \& Disabilities | ISSN: 2381-8670

Journal Of Plant Science Current Research | ISSN: 2639-3743

Journal Of Practical \& Professional Nursing | ISSN: 2639-5681

Journal Of Protein Research \& Bioinformatics

Journal Of Psychiatry Depression \& Anxiety | ISSN: 2573-0150

Journal Of Pulmonary Medicine \& Respiratory Research | ISSN: 2573-0177

Journal Of Reproductive Medicine Gynaecology \& Obstetrics | ISSN: 2574-2574

Journal Of Stem Cells Research Development \& Therapy | ISSN: 2381-2060

Journal Of Surgery Current Trends \& Innovations | ISSN: 2578-7284

Journal Of Toxicology Current Research | ISSN: 2639-3735

Journal Of Translational Science And Research

Journal Of Vaccines Research \& Vaccination | ISSN: 2573-0193

Journal Of Virology \& Antivirals

Sports Medicine And Injury Care Journal | ISSN: 2689-8829

Trends In Anatomy \& Physiology | ISSN: 2640-7752

Submit Your Manuscript: https://www.heraldopenaccess.us/submit-manuscript 